Richard Pankhurst

Addis Ababa

\title{
THE SHORT-LIVED NEWSPAPER ABYSSINIA (1935-1936): A MEMORY OF THE LEAGUE OF NATIONS.
}

Italy's invasion of Ethiopia, on 3 October 1935, was important not only for the two protagonists, but also for the wider international community. Insight into the impact of the conflict on the League of Nations, and on public opinion in its principal member state, Great Britain, can be seen in the pages of a today little-known newspaper entitled Abyssinia. ${ }^{1}$ This publication, which ran for a little short of four months, but achieved a circulation of no less than 90,000 copies a week, was one of the first to be devoted - even though tangentially — to Ethiopia, and deserves a place in the history of political literature on the country.

The newspaper was issued by the principal - and very prestigious British non-governmental internationalist association: the League of Nations Union, which had been founded after World War I to rally support for the then new League of Nations. The Union, since 1920, had published a monthly promotional newspaper entitled Headway, which bore the self explicatory sub-title «The Journal of the League of Nations Union». Faced with the Fascist invasion of Ethiopia at the beginning of October 1935, which was to test the League of Nations to breaking point, the Union on 23 October issued a special 4-page supplement to Headway. Entitled Enforcing Peace, it was en-

${ }^{1}$ For the background to the Italian invasion of Ethiopia see Angelo Del BocA, The Ethiopian War 1935-1941, Chicago and London 1965; and ANTHONY MockLER, Haile Selassie's War, London 1984. On British public opinion towards the war see Gaetano Salvemini, Prelude to World War II, London 1953; Frank Hardie, The Abyssinian Crisis, London 1974; DANIEL Waley, British Opinion and the Abyssinian War 1935-1936, London 1975; Richard PAnkhurst, Sylvia Pankhurst: Counsel for Ethiopia a Biographical Essay on Ethiopian, Anti-Fascist and Anti-Colonial History 1934-1960, Hollywood, California, 2003; and INALCO (ed.), La guerre d'Ethiopie et l'opinion mondiale 1934-1941, Paris 1986. On the history of the Ethiopian and related press see Richard PANKhurst, «The History of Education, Printing, Newspapers, Book Production, Libraries and Literacy in Ethiopia», Ethiopia Observer 6 (1962), 321-389; and Richard PAnkhurst, "CCorrespondance d'Ethiopie": The History of a Pro-Ethiopian Newspaper (1926-1933)», in: VerEna Böll — DenIS Nosnitsin - Thomas Rave - Wolbert Smidt - Evgenia Sokolinskaia (eds.), Studia Aethiopica. In Honour of Siegbert Uhlig on the Occasion of his 65th Birthday, Wiesbaden 2004, 203-219. 
visaged as a weekly newspaper, but only one issue in fact appeared, for it was replaced, on 20 November, by a supplement with the entirely different name Abyssinia. This latter publication, with which we are here concerned, appeared weekly, and, like its short-lived predecessor, ran to four pages. Produced in the flush of popular British anti-war enthusiasm it was given what was to turn out the over-optimistic sub-title $A$ Weekly Newspaper of the League of Nations in Action [sic]. It was from the bibliographical point of view somewhat bizarrely referred to as «No. 2» (being in effect treated as a sequel to the earlier one-issue supplement Enforcing Peace).

Efforts were made to give the new publication a large and influential readership. An advertisement in the paper stated that copies would be posted free-of charge to anyone so requesting. The newspaper Abyssinia, despite its title, published virtually no information about the history, economy, politics or culture of that country, and nothing on the Fascist military operations therein. The paper, as perhaps befitted an organ of the League of Nations Union, confined itself to defending the League's action (or inaction) in relation to the invasion - and devoted much of its attention to the question of League of Nations Sanctions against the aggressor, Italy. Sanctions were then of major international interest, the more so as they had up to that time had never been applied. Defence of the League also led the paper on occasion into discussions on the question of Ethiopian slavery, which the Italian Government used as a justification, or excuse, for its invasion. Curiously, in view of the publication's pro-Ethiopian stance, no mention was made of the invader's use of mustard gas, though this had by then been widely reported in the British and international press.

The scope and character of the paper was laid down in its first issue, for 20 November, which carried a front-page article entitled «Peace and the Parties», by the Union's President, Viscount Cecil, in which he declared that the «Abyssinian crisis» was «far from over». Writing in the aftermath of a British General Election, which had returned a large Conservative majority, he warned that pledges issued at such times were «not always kept», and argued that there was therefore «no time to rest», for «the price of peace, no less than liberty», was «eternal vigilance». A further article on «Sanctions in Force» argued that 15 November of that year (1935) was «a crucial date» in the history of the League, for it was «the first time» that member states were «required to fulfil their obligations» by taking «drastic action against a Great Power [i. e. Italy] guilty of aggression». The article went on to assert that no fewer than 53 states had agreed to impose Sanctions. Another article, entitled «The Right Answer» (which was continued in the next issue) addressed itself to various points which «puzzle[d] the man in the street». The article thus sought to dispel such doubts as whether Sanctions against Italy would lead to a European war, or prove a greater burden on Britain than on Italy. A final article in that first issue, headed «The Fascist Considers Life as Battle», quo- 
ted from several of Mussolini's more reactionary and belligerent speeches: one proclaimed that the entire history of man was the history of the "progressive limitation of liberty», while another declared that «all the world must recognise the will and spirit of fascist Italy». The second issue of Abyssinia, which was dated 27 November, further developed the League case for Sanctions. The paper thus reproduced the text of a speech which Anthony Eden, the British Minister for League of Nations Affairs, had delivered to the League of Nations Union. In it he argued that «for the first time in history fifty nations have undertaken collective action» — through Sanctions; and had thus committed themselves to «a new peace system for the world». Abyssinia, as a propaganda organ of the League of Nations Union, never expressly criticised the limited, and, as many would argue, ineffective, character of the League's Sanctions, but urged, in a more positive and constructive vein, that they should be extended of to include petrol. This was emphatically urged in the ensuing article which bore telling title «No War Without Oil. Embargo Would Stop the Italian Advance». The case for Sanctions was driven home by W. Arnold Foster, a prominent supporter of the Union, who declared that Sanctions were «a Necessary Part of the Price of Peace».

Support for the League, and for the principle of Collective Security against Aggression, was voiced in the issue of 4 December, which carried a frontpage article by the Archbishop of York, William Temple. Declaring it God's will that the nations of the world should collaborate together in the cause of peace, he argued that the choice before mankind was one, as the title of his article put it, between «Fear and Uncertainty or Safety and Enterprise?» Advocacy of the League led the periodical Abyssinia into a vigorous rebuttal of Italian propaganda, which was then widely distributed in Britain and other Western countries. A two-page article, entitled «What Italy Says — and the Answer», which also appeared on 4 December, drew attention to the fact that such propaganda was «busy in Great Britain», and that it was «not always evident» who inspired or paid for many accounts of Ethiopian «barbarism», and of Italy's supposed «civilising» efforts in Africa. Reverting to the League policy a more speculative article by the French intellectual Andre Maurois asked readers to «suppose» the League had existed at the time of the beginning of World War I in 1914, and concluded that «though not certain ... it was at least probable that war might have been averted». A further article in the same issue enthusiastically reported that the British Government had decided, on 2 December, that an «Oil Ban Will be Enforced». By the second week of December 1935 it was becoming apparent that Sanctions were failing, that the Italians had retained the military initiative, and that the British and French Governments were beginning to consider a «compromise peace» — which would probably in fact constitute a surrender to Italy. To forestall any such move Professor Gilbert Murray, the League of Union's chairman, wrote a front page article in Abyssinia on 11 December entitled, «The authority of the 
League Must be Vindicated». He urged that Italy, as «a great Power» must not be allowed to «destroy the League system». Other potentially aggressor powers were «watching», he declared, with a view to emulating Mussolini's policy of aggression, and «if Italy defeated the League» the damage might be «practicably irreparable». The paper also ran a news item entitled «Britain Leads the World: Country Supports Government in Full League Policy». In support of this optimistic statement the article quoted a then famous statement by the British Foreign Secretary, Sir Samuel Hoare, to the effect that his country's support for the League was «no variable and unreliable sentiment but a principle of international conduct» to which his government held with «firm, enduring and universal persistence». A final article in the same issue rebutted further Italian propaganda on the Ethiopian war, by quoting from some of Mussolini's more bellicose speeches.

The League of Nations Union, and its newspaper Abyssinia, was deeply shocked, like British public opinion in general, by the Hoare-Laval Plan for a «compromise peace», which was leaked to the European press on 9 and 10 December 1935. The paper at once responded, on 18 December, by publishing a long article by one of the plan's most bitter critics, Vyvyan Adams MP, who announced his intention to move a motion in the British House of Commons to the effect that «this House will not assent to any settlement of the Italo-Ethiopian dispute which ignores our International Obligations under the Covenant of the League of Nations by granting the aggressor State greater concessions after its unprovoked aggression than could have been obtained by peaceful negotiations». An accompanying map showed that the plan would have in one way or another given Italy virtually half of Ethiopia. Publicity was also given, in the same issue, to a leading article in The Times, which put the main blame for the pact on the French Government. The article further declared that opposition to the plan was «accurately reflected» throughout the British press, for it reached newspaper offices «by letter and telegram», was «heard in the lobbies of Parliament, in the constituencies, in the City, and indeed wherever men meet». It was the Government's duty to establish, The Times insisted, that «aggression does not pay». Sir Samuel Hoare, as result of the great surge of public indignation described in the paper, was obliged to resign, on 19 December 1935.

Support for the extension of Sanctions to include oil meanwhile continued to be voiced in Abyssinia with increasing urgency. The issue for 8 January 1936, thus bore the banner heading, «Oil Must Be Banned. A Challenge the League Dare Not Evade», and declared, «The world must face the oil challenge ... Italy ... needs oil in vast quantities to move much of her sea transport, and all her supply lorries, her armoured cars, her tanks, her aeroplanes...» As the paper nevertheless noted, Sir Samuel Hoare in his resignation speech mentioned that Mussolini had said that «Italy would regard the oil embargo as a military sanction or an act involving war against them». This 
contention was rejected in an accompanying article which claimed that the fears of Hoare and Laval were «groundless», for Britain would not «stand alone ... should Italy decide to attack her for daring to apply economic sanctions decided upon by the League».

International tensions were growing. The issue of Abyssinia for $15 \mathrm{Janu}-$ ary 1936 thus bore an opening article entitled «The League defends the Victim», which sought to justify the precautionary despatch by the British of warships, planes and men to the Mediterranean. No less important was an article on «The Meaning of American Neutrality», which once again reiterated the importance of applying Sanctions to oil, and concluded: «the objects of the United States and the objects of the League are not opposed [to each other]. The President is being given powers which will enable him to restrict American shipments of oil to Italy to normal peace-time quantities. He will use those powers». A final article in the same issue was almost the first to consider the character of the Italo-Ethiopian war as such. Entitled «A Long War is a Cruel War», the paper declared that «Every week men are mutilated and killed ... Every week the struggle grows more desperate». Elaborating on this argument the article - whose author was either badly informed or giving way to wishful thinking — claimed that «hints» were «being heard» that the Italian aggression had «definitely failed», and that Italian power was «visibly crumpling up». The time had therefore come, the article argued, for the Oil Sanction, which would not only «save the people of Abyssinia», but «avert the imposition of misery» on that of Italy.

The issue of Abyssinia for 22 January carried an important speech to his constituents by Anthony Eden, the newly appointed Secretary of State for Foreign Affairs, in which he emphasised two «essential» points for the League. The first was, that «aggression should not be allowed to succeed». The second was, that League members, acting together, should bring it home to any would-be aggressor, that «peaceful negotiation and not aggression» was «not the best, but the only successful means of removing discontents». A further article, entitled «World Power Must Assume World Leadership», declared that although the League was «a true democracy of nations», more was in fact expected from Britain as its strongest member. Similar views were expounded in the newspaper's issue for 29 January, which commemorated the accession of the new King, Edward VIII, who, it declared, «Faces a Great Task and a Great Opportunity», and whose country faced the need «to adjust herself to her place in a new world order so that she may play there a part worthy of herself». Turning to real issues the paper appealed in a two-page article for «No More Delays», for «All League Members», it claimed, were «Agreed: Italy's Oil Shipments Must Be Stopped». Evidence that the views of the League of Nations Union were not universally accepted, even in Britain, was provided in the same issue, which published an article asking the question «Is Italy Right?» — to which two very different replies were, sur- 
prisingly, afforded. The first, by the radical but on this issue quirky, playwright George Bernard Shaw, argued that the struggle was between Italy, «a modern civilised State», and «the barbarism of the Danakil». The second reply, by the pacifist author Sir Norman Angell, argued for the settlement of disputes, not by force of arms, but by the arbitration of third parties. Advocacy of the League as the sole means of preserving peace was likewise expounded in the paper's issue for 5 February. It reproduced the text of an important speech by the South African premier General Jan Christian Smuts, in which he declared that «War Talk», by the Italians, was «Mainly Bluff», and called on his compatriots to «Be Strong and Stand Fast», for «The Only Security in the World [lay] In the League». Defending the League's support for Ethiopia as the victim of aggression, the paper also published a forceful article which with the title «Italy says: she fighting against slavery. The facts tell a different story». The article argued that Italy had «not attacked Abyssinia because Abyssinia is a slave-trading society». This conclusion was reinforced in a further article entitled «The Fight against the Red Sea Slave Trade», which quoted eye-witness observers, who reported the export of slaves, as well as brutal floggings, in nearby Italian colony of Eritrea. A final article in the same issue happily reported that the Legaue had «decided in principle» that Sanctions should include oil.

The importance of an Oil Embargo was once more reiterated by Abyssinia in its issue for 12 February, which bore the dramatic heading «League Should Ban Oil Now», and for the first time published an official statement from the League of Nations Union's Excessive Committee. It declared that the Committee had: «never altered its opinion that States members of the League ought to withhold from the Covenant-breaking State [i. e. Italy] all supplies of petroleum and its derivatives...». «That the population of a member State should be bombed by aeroplanes supplied with oil fuel purchased from other States members of the League is itself a breach of Article Sixteen [of the League Covenant] and constitutes a deplorable travesty of the Covenant». A further article in the same issue reiterated that Italy had «not attacked Abyssinia because Abyssinia is a slave-owning and slave-trading country», but because «Italy was for conquest». The question of Oils Sanctions received even greater attention in the issue of 19 February 1936, which explained that Italy was then purchasing 4,000,000 tons of oil a year, the greater part of it from Rumania and the USSR, followed by the Netherlands, Iran and the USA. An Oil Embargo by League members and the USA, it was argued, «would end the war in four months». This thesis was reinforced by the reproduction in the paper of comments from the Indian press. One, in the Hindu, of Madras, was interesting in that it made reference to a feature of the war which Abyssinia itself had never mentioned, i. e. Italian «air raids on women and children... and repeated bombings of the Red Cross and Red Crescent units». Abyssinia's support for the League was expounded yet again in its issue for 26 Feb- 
ruary 1936, which bore the hopeful slogan: «The League Will Work — If We Do Our Part». An accompanying article proclaimed the need for «a strong League policy», which had been expressed in a House of Commons debate only two days earlier. In it Foreign Secretary Eden, had claimed that the British Government had not «departed neither from their original decision of principle regarding the oil sanction..., nor from their resolve to take their full part with others in such collective action as the League may decide on».

Not dissimilar statements were uttered by Liberal and Labour MPs. One of the former, Sir Archibald Sinclair had most forcefully declared the war between Italy and Abyssinia «a vital test of the efficacy of the League and of the loyalty of its members to the Covenant». The next issue of Abyssinia did not appear as expected early in March, 1936. Publication was in fact delayed, apparently for lack of funds, until 11 March, when it was announced that it would be published «once a fortnight until further notice» — but no further issue was in fact ever published. The issue of 11 March was thus in fact the last to appear. It carried an emphatic article by Professor Gilbert Murray, entitled «Resist War-Maker: Protect Peace-Keeper». In it he declared that «every war-maker in Europe is watching the contest between the arch-warmaker Mussolini and the League, which is trying to control him», and prophesied, «If Mussolini wins the world will have been made safe for war». This last issue published three further articles, which were imbued, as so often, with wishful thinking. The first announced that Ethiopia and Italy had both expressed willingness to negotiate peace; the second reiterated that President Franklin Roosevelt too was opposed the increased sales of oil to Italy; the third declared that «all nations» would be «Beneficiaries of Peace». With those words the enthusiastic, but short-lived newspaper Abyssinia ceased publication. Despite its earlier hope that the Italian invasion was «visibly crumpling up», and that League Sanctions would be extended to include oil, the Emperor's army was decisively beaten at May Chew on 31 March 1936, the Italian army entered Addis Ababa little over a month later, on 5 May, and the League Assembly voted for the total ending of Sanctions on 4 July. Events in the next three or four years were, however, to show that the world had become «safe for war», as Gilbert Murray had prophesied — and there were no «Beneficiaries of Peace». 


\section{SUMMARY}

The Italian Fascist invasion of Ethiopia, on 3 October 1935, led to considerable excitement - and condemnation - throughout the world. In Britain, the League of Nations Union, an entirely non-Governmental organisation, founded a weekly pro-Ethiopian newspaper entitled Abyssinia. Somewhat optimistaically sub-titled «The League of Nations in Action», it first appeared on 20 November 1935, and advocated League of Nations Sanctions against the aggressor, as well as support for the League in general. The paper, which thus appeared at a critical period, published articles by prominent British advocates of Collective Security against aggression, and, immediately achieved an influential circulation. The abandonment of Sanctions brought an end to the publication. The last issue appeared on 11 March 1936 - after only four months of publication. Though thus shortlived, the paper constitutes a valuable historical source for our understanding of a significant period of Ethiopian history, and that of the League. 